
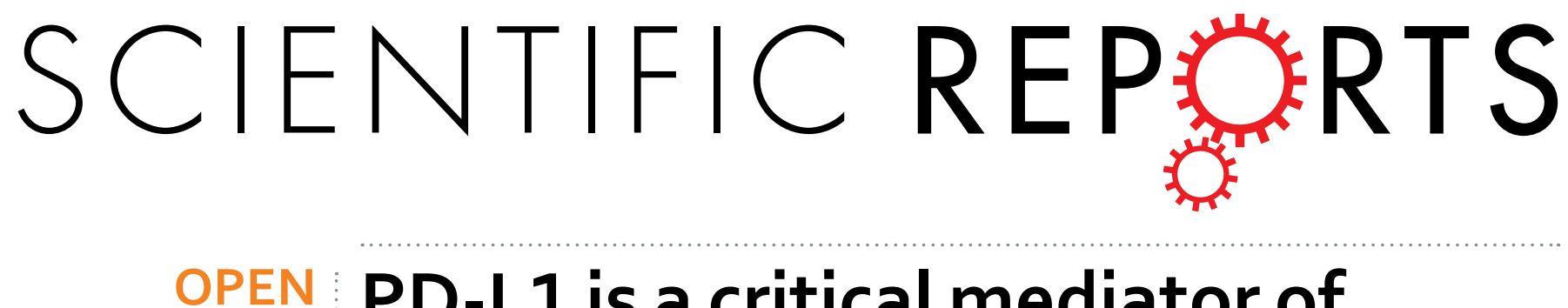

\title{
PD-L1 is a critical mediator of regulatory $B$ cells and $T$ cells in invasive breast cancer
}

Received: 12 July 2016

Accepted: 29 September 2016

Published: 20 October 2016

\section{Honggeng Guan ${ }^{1,2, *}$, Yuqiu Wan ${ }^{2, *}$, Jing Lan ${ }^{2, *}$, Oin Wang ${ }^{3}$, Zhangyu Wang ${ }^{2}$, Yecheng $\mathrm{Li}^{4}$, Jiqing Zheng ${ }^{1}$, Xueguang Zhang ${ }^{5}$, Zemin Wang ${ }^{6}$, Yueping Shen ${ }^{7}$ \& Fang Xie ${ }^{1}$}

Regulatory T cells (Tregs), a key mediator in regulating anti-tumor immune suppression, tumor immune escape, metastasis and relapse, are considered an important therapeutic target in immunotherapy of human cancers. In the present investigation, elevated $\mathrm{CD} 19^{+} \mathrm{CD} 24^{+} \mathrm{CD} 38^{+}$regulatory $\mathrm{B}$ cells (Bregs) were observed in PBMCs of invasive carcinoma of breast (IBCa) patients compared with that in patients with fibroadenoma (FIBma) or healthy individuals, and the positive correlation existed between Bregs and $\mathrm{CD}_{4}{ }^{+} \mathrm{CD} 25^{+} \mathrm{CD} 127^{-}$Tregs $(r=0.316, P=0.001)$. We found that PD-L1 expression was higher on Bregs in IBCa patients compared with patients with FIBma or healthy individuals $(P<0.05$, respectively), and that a tight correlation exists between $\mathrm{CD} 19^{+} \mathrm{CD} 24^{+} \mathrm{CD} 38^{+} \mathrm{PD}-\mathrm{L1}^{+}$Bregs and $\mathrm{CD} 19^{+}$ CD24 ${ }^{+}$CD $38^{+}$Bregs $(r=0.267, P=0.007)$, poor TNM phases and up-regulated expression of PD-L1 on Bregs. The pattern of PD-1 expression on $\mathrm{CD4}^{+} \mathrm{T}$ cells indicated that high level of PD-1 ${ }^{\mathrm{hi}}$ expressed on $\mathrm{CD}^{+} \mathrm{CD}^{2} 5^{+} \mathrm{CD} 127^{+}$effector T cells $(P<0.001)$. More importantly, the presence of PD-L1 on Bregs was positively correlated with Tregs $(r=0.299, P=0.003)$, but negatively correlated with PD- ${ }^{\text {hi }}$ effector $T$ cells $(r=-0.22, P=0.031)$. Together, results of the present study indicated that PD-L1 is an important molecule on Bregs, mediated the generation of Tregs in IBCa.

Regulatory B cells (Bregs), a subset of B cells, play a suppressive role in autoimmune diseases, inflammation, and anti-tumor immune respons $\mathrm{e}^{1-5}$. Based on the expression of various surface molecules, several populations of Bregs have been reported including B10 cells ${ }^{6}, \mathrm{CD} 1 \mathrm{~d}^{\text {hi }} \mathrm{CD}^{+} \mathrm{CD} 19^{+} \mathrm{B}$ cells ${ }^{7}, \mathrm{CD} 19^{+} \mathrm{CD} 24^{+} \mathrm{CD} 38^{+} \mathrm{B}$ cells ${ }^{2}$ or $\mathrm{CD} 19^{+} \mathrm{CD} 24^{+} \mathrm{CD} 27^{+} \mathrm{B}$ cells ${ }^{8}$ and so on. Recently, IL-10-producing was recognized as one of the most important characters of functional Bregs ${ }^{6,9-11}$. Increasing evidence showed that, IL-10, as an inhibitory cytokine, suppresses the differentiation and proliferation of Th17, inhibits the secretion of IFN- $\gamma$, and reduces the accumulation of NK cells ${ }^{5}$. In one of our early studies, we also found high percentage and density of $\mathrm{CD}_{1} 9^{+} \mathrm{B}$ cells in the tissues of invasive carcinoma of breast (IBCa) which expressed IL-10 in cytoplasm. We demonstrated that CD $19^{+}$B cells from IBCa patients but not that from healthy individuals could induce the expansion of Treg cells in vitro ${ }^{12}$. The immunosuppressive effects of Bregs have also been shown to be mediated via by promoting Tregs in mice models of autoimmune diseases ${ }^{13}$, and non-autoimmune diseases including cancers ${ }^{14}$. Nevertheless, the function and mechanism of Bregs in immune response remain poorly understood.

Programmed death-ligand 1 (PD-L1), as a critical suppressive molecule, constitutively expresses on B lymphocytes, T lymphocytes, dendritic cells and monocytes ${ }^{15-17}$. The expression of PD-L1 is induced by ligation of cell surface receptors and/or stimulation with the $\mathrm{T}_{\mathrm{H}} 1$-associated cytokine IFN $\gamma^{15}$. Its receptor, the programmed death-1 (PD-1), is up-regulated in activated T or B cells ${ }^{17}$. The PD-1/PD-L1 signaling axis has been shown to be a critical regulator for maintaining peripheral tolerance ${ }^{15}$. 
It is clear that there was an increased number of $\mathrm{CD} 19^{+} \mathrm{CD} 24^{+} \mathrm{CD} 38^{+}$Bregs in the peripheral blood mononuclear cells (PBMCs) of IBCa patients ${ }^{12}$, however it is not currently known whether PD-1/PD-L1 expressed on $\mathrm{CD} 19^{+} \mathrm{CD} 24^{+} \mathrm{CD} 38^{+}$Bregs acts exclusively on Tregs or other components of IBCa. In the present study, in an effort to further understand the role of Bregs in the etiology and pathogenesis of breast cancer, we examined $\mathrm{CD}^{+} \mathrm{T}$ cells, CD19+ $\mathrm{B}$ cells and their subsets in PBMCs of breast tumor patients, and investigated the relationship among $\mathrm{CD} 4^{+} \mathrm{T}$ cells, $\mathrm{CD} 19^{+} \mathrm{B}$ cells and their subsets in breast tumor.

\section{Results}

$\mathrm{CD}^{+}{ }^{+} \mathrm{CD} 25^{+} \mathrm{CD} 127^{\text {low/- }}$ Tregs predominated in PBMCs of IBCa patients. $\mathrm{CD} 4^{+} \mathrm{T}$ lymphocytes, regarded as $\mathrm{T}$ helper cells, regulate the immune responses by activating other immune cells or dividing to Tregs to suppress immune reaction. In the present study, we evaluated the percentages of $\mathrm{CD} 4^{+} \mathrm{T}$ cells and its subsets in the PBMCs of breast tumor patients. The percentages of $\mathrm{CD}^{+} \mathrm{T}$ cells in PBMCs of health individuals $(19.90 \pm 9.02 \%)$, fibroadenoma (FIBma) $(22.98 \pm 7.51 \%)$ and IBCa patients $(20.74 \pm 8.84 \%)$ were comparable $\left(P>0.05\right.$; Fig. 1A,E). However, The percentage of $\mathrm{CD} 4{ }^{+} \mathrm{CD} 25^{+} \mathrm{CD} 127^{\text {low }}-\mathrm{T}$ cells was significantly higher in the PBMCs of IBCa patients $(6.06 \pm 2.17 \%)$ compared with that in FIBma patients $(2.91 \pm 1.06 \%)$ and health individuals $(2.28 \pm 0.79 \%)(P<0.05$ for both; Fig. $1 \mathrm{~A}, \mathrm{~B})$. Similarly, the ratio of CD4 ${ }^{+} \mathrm{CD} 25^{+} \mathrm{CD} 127^{\mathrm{low} /-}$ Tregs and $\mathrm{CD} 4^{+} \mathrm{T}$ cells was among the highest in IBCa patients in comparison with health individuals and FIBma patients $(P<0.05$; Fig. 1F).

Because PD-1 is an important molecule in immune suppression, we then evaluated the expression of PD-1 on $\mathrm{CD} 4^{+} \mathrm{T}$ cells and its subsets including $\mathrm{CD} 4{ }^{+} \mathrm{CD} 25^{+} \mathrm{CD} 127^{\text {low/- }}$ Tregs in PBMCs. Based on the the expression level of PD-1, each cell population was divided into two distinct subpopulations, PD- $1^{\text {lo }}$ and PD- ${ }^{\text {hi }}$ (Fig. S1). Although the expression levels of PD-1 on $\mathrm{CD} 4{ }^{+} \mathrm{CD} 25^{+} \mathrm{CD} 127^{\text {low }}-$ Tregs were significantly different between the PBMCs of FIBma $(55.19 \pm 9.98 \%)$ and healthy individuals $(39.95 \pm 16.10 \%)(P<0.05$; Fig. 1C,D), no significant difference between IBCa patients $(48.10 \pm 18.60 \%)$ and healthy individuals $(P>0.05$; Fig. 1C,D) were seen. However, the percentage of PD $-1^{\text {hi }} \mathrm{CD} 4{ }^{+} \mathrm{CD} 25^{+} \mathrm{CD} 127^{\text {low/ }}-$ Tregs $(9.57 \pm 7.27 \%)$ were significantly lower than the PD- ${ }^{\text {hi }}$ $\mathrm{CD} 4^{+} \mathrm{CD} 25^{+} \mathrm{CD} 127^{+}$T cells $(20.00 \pm 22.15 \%)$ in IBCa $(P<0.05$; Fig. $1 \mathrm{G})$. The percentage of PD- $1^{\text {hi }} \mathrm{CD} 4{ }^{+} \mathrm{CD} 25^{-}$ $\mathrm{T}$ cells was $13.92 \pm 10.15 \%$, which was not significantly different from PD- ${ }^{\text {hi }} \mathrm{CD} 4^{+} \mathrm{CD} 25^{+} \mathrm{CD} 127^{\text {low } /-}$ Tregs or $\mathrm{PD}-1^{\text {hi }} \mathrm{CD} 4^{+} \mathrm{CD} 25^{+} \mathrm{CD} 127^{+}$effector T cells (Fig. 1G). In contrast, there were statistically significantly more PD- $1^{\text {lo }}$ $\mathrm{CD} 4{ }^{+} \mathrm{CD} 25^{+} \mathrm{CD} 127^{\text {low } /-}$ Tregs $(37.17 \pm 19.27 \%)$ than PD $1^{\text {lo }} \mathrm{CD} 4{ }^{+} \mathrm{CD} 25^{+} \mathrm{CD} 127^{+}$effector $\mathrm{T}$ cells $(31.03 \pm 20.84 \%)$ and $\mathrm{PD}-1^{\mathrm{lo}} \mathrm{CD} 4^{+} \mathrm{CD} 25^{-} \mathrm{T}(23.87 \pm 19.68 \%)(P>0.05$ and $P<0.05$, respectively) in IBCa (Fig. $1 \mathrm{H})$.

Further analysis of the relationship among the percentages of CD $4^{+} \mathrm{T}$ cells, CD $4^{+} \mathrm{CD} 25^{+} \mathrm{CD} 127^{\text {low }}-$ Tregs, and $\mathrm{CD} 4{ }^{+} \mathrm{CD} 25^{+} \mathrm{CD} 127^{\text {low } /-} \mathrm{PD}-1^{+}$Tregs in IBCa and the histopathological characteristics of IBCa revealed that the $\mathrm{CD}^{+} \mathrm{T}$ cells were higher in patients of 49 years or older $(P=0.047)$ (Table 1$)$. The percentage of the above cell populations were not significantly different among all other histopathological characters examined including tumor grade, status of metastasis, TNM staging, ER, PR and HER2 status, as well as tumor size (Table 1).

$\mathrm{IL}-10^{+} \mathrm{B}$ cells were enriched in the $\mathrm{CD} 19^{+} \mathrm{CD} 24^{+} \mathrm{CD} 38^{+} \mathrm{B}$ cell population. Different from the positive regulation in immune response, the new functions of $\mathrm{B}$ cells in antitumor immunity warrant further investigation. $\mathrm{CD} 19^{+} \mathrm{IL}-10^{+} \mathrm{B}$ cells, also known as $\mathrm{B} 10$, were regarded as regulatory $\mathrm{B}$ cells which play an important role in immune suppression. In present study, we evaluated the percentage of CD19+ $\mathrm{B}$ cells in PBMCs of breast tumor patients. No significant difference was found in the percentage of CD19+ $\mathrm{B}$ cells in PBMCs among FIBma, IBCa patients and healthy individuals $(5.89 \pm 2.44 \%, 5.31 \pm 3.23 \%$, and $4.75 \pm 2.16 \%$, respectively) (Fig. $2 \mathrm{~A})$. However, the level of IL-10 secreting CD19+ $\mathrm{B}$ cells was higher in IBCa patients compared with that in FIBma patients $(2.31 \pm 1.01 \%$ vs $1.12 \pm 0.41 \% ; P=0.046)$ (Fig. $2 \mathrm{~B})$.

We have previously demonstrated that $\mathrm{CD} 19^{+} \mathrm{CD} 24^{+} \mathrm{CD} 38^{+} \mathrm{B}$ cells were regulatory B cells in breast cancer ${ }^{12}$. In the current study, to further determine the phenotype of CD $19^{+} \mathrm{IL}-10^{+} \mathrm{B}$ cells in PBMCs of IBCa, isolated $\mathrm{CD} 19^{+} \mathrm{IL}-10^{+} \mathrm{B}$ cells were labeled with anti-CD24 and anti-CD38 antibodies and analyzed by flow cytometry. A significantly higher percentage of $\mathrm{CD} 24^{+} \mathrm{CD} 38^{+}$in the $\mathrm{CD} 19^{+} \mathrm{IL}-10^{+}$group $(39.18 \pm 5.98 \%)$ was seen compared to that in the CD19+IL- $10^{-}$group $(8.87 \pm 4.08 \%)(P=0.001)$ (Fig. $\left.2 \mathrm{C}, \mathrm{D}\right)$. Consistent with the findings of our previous study ${ }^{12}$, the level of IL-10 was significantly higher in the CD $19^{+} \mathrm{CD} 24^{+} \mathrm{CD} 38^{+} \mathrm{B}$ lymphocytes $(39.18 \pm 18.91 \%)$ than in the $\mathrm{CD} 19^{+} \mathrm{CD} 24^{-} \mathrm{CD} 38^{+} \mathrm{B}$ cells $(20.72 \pm 13.01 \%)$ and $\mathrm{CD} 19^{+} \mathrm{CD} 24^{+} \mathrm{CD} 38^{-} \mathrm{B}$ cells $(20.48 \pm 13.46 \%)(P=0.023$ and $P=0.0231$, respectively) (Fig. 2E).

$\mathrm{CD} 19+\mathrm{CD} 24^{+} \mathrm{CD} 38^{+}$Bregs and its subsets were expanded in breast cancer patients. Subsequently, we investigated the distribution of $\mathrm{CD} 19^{+} \mathrm{CD} 24^{+} \mathrm{CD} 38^{+}$Bregs and various subsets in the PBMCs of breast tumor patients. In comparison with FIBma patients and healthy participants $(4.48 \pm 1.91 \%$ and $4.49 \pm 2.48 \%$, respectively), the percentage of $\mathrm{CD} 19^{+} \mathrm{CD} 24^{+} \mathrm{CD} 38^{+} \mathrm{B}$ cells was significantly higher in the PBMCs of IBCa patients with $10.99 \pm 5.70 \%(P<0.05)$ (Fig. 3A,B).

Similar to the experiments in $\mathrm{CD} 4^{+} \mathrm{T}$ cells and Tregs, we determined the expression pattern of the negative immune regulator PD-L1 in B cells and CD $19^{+} \mathrm{CD} 24^{+} \mathrm{CD} 38^{+}$Bregs (Fig. 3C). Significantly higher level of $\mathrm{CD} 19^{+} \mathrm{CD} 24^{+} \mathrm{CD} 38^{+} \mathrm{PD}-\mathrm{L} 1^{+}$subset $(83.74 \pm 19.32 \%)$ was observed in the PBMCs of IBCa patients compared with that in FIBma patients $(78.40 \pm 13.96 \%)$ or healthy individuals $(61.13 \pm 20.51 \%)(P<0.05$, respectively $)$ (Fig. 3C,D). In addition, both the PD-L1 $1^{\text {lo }}$ and PD-L1 $1^{\text {hi }}$ expression were found to be significantly higher on $\mathrm{CD} 19^{+} \mathrm{CD} 24^{+} \mathrm{CD} 38^{+}$Bregs $(42.36 \pm 23.27 \%$ and $14.02 \pm 16.99 \%)$ compared with non-Bregs $(24.58 \pm 16.51 \%$ and $3.92 \pm 8.18 \% ; P<0.001$ for both) (Fig. $3 \mathrm{E}, \mathrm{F}$ ).

We further investigated the relationships among the levels of $\mathrm{CD} 19^{+} \mathrm{B}$ cells, $\mathrm{CD} 19^{+} \mathrm{CD} 24^{+} \mathrm{CD} 38^{+}$Bregs, as well as $\mathrm{CD} 19^{+} \mathrm{CD} 24^{+} \mathrm{CD} 38^{+} \mathrm{PD}-\mathrm{L1}^{+}$Bregs in IBCa and the histopathological characteristics of IBCa, and found that the $\mathrm{CD} 19^{+} \mathrm{B}$ cells were significantly higher in patients with tumors more than $3 \mathrm{~cm}(P=0.019)$ and $\mathrm{CD} 19^{+}$ $\mathrm{CD} 24^{+} \mathrm{CD} 8^{+} \mathrm{PD}-\mathrm{L} 1{ }^{+}$Bregs were among the highest patient at TNM stage $\mathrm{T} 4(P=0.011)$ (Table 2$)$. 
A

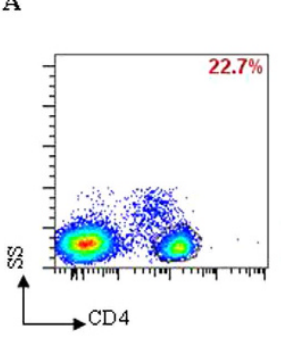

C

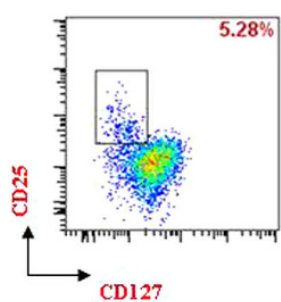

E

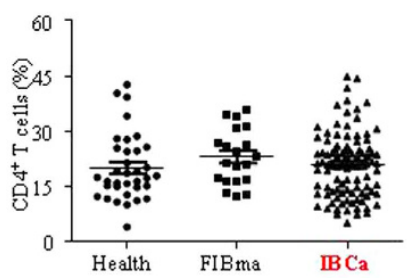

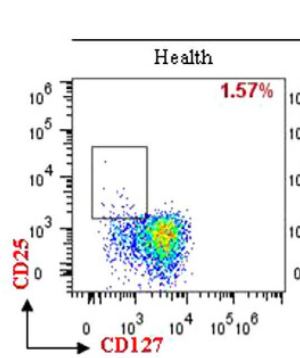

Gated to SSCD4 $4^{+}$

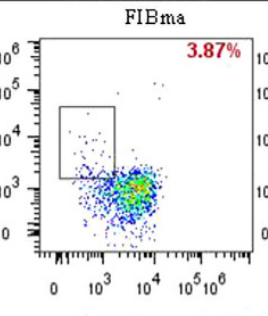

Gated to $\mathrm{CD} 25^{+} \mathrm{CD} 127^{\text {lowot }}$.
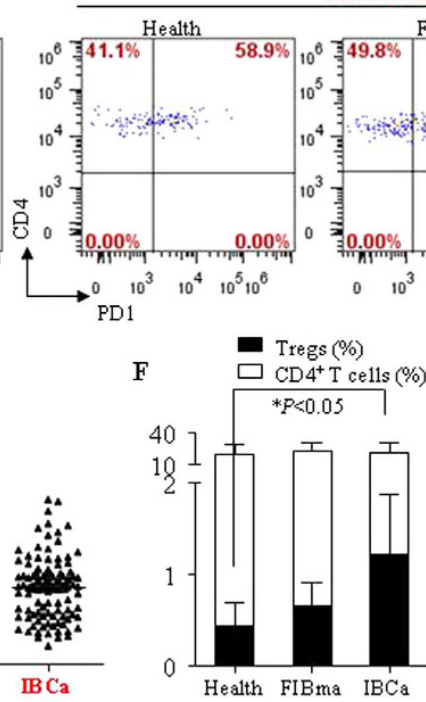

FIBma

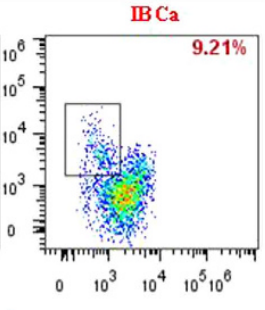

B

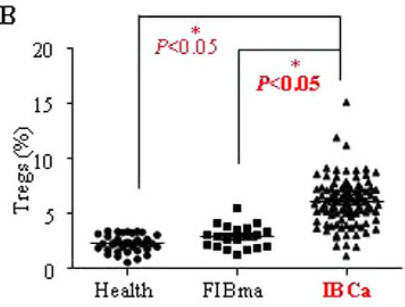

D

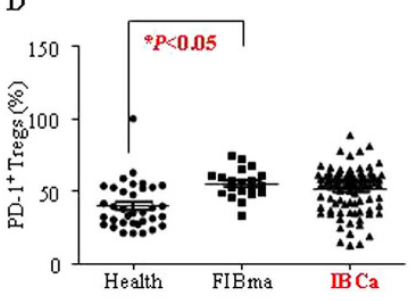

H

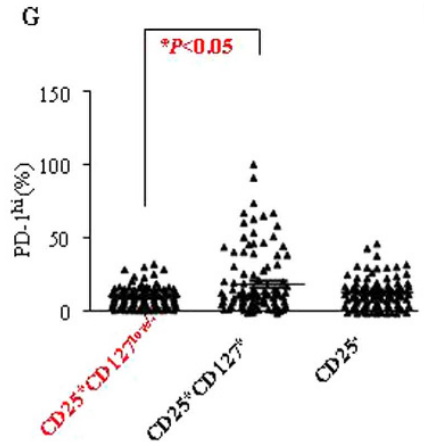

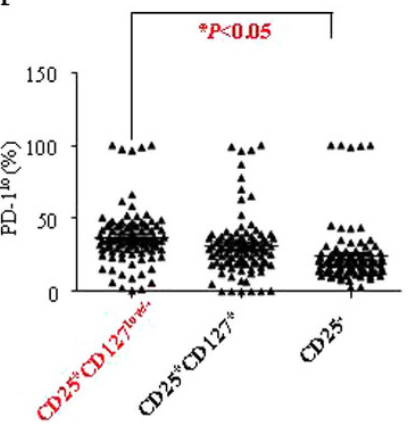

Figure 1. $\mathrm{CD}^{+} \mathrm{CD}^{+} 5^{+} \mathrm{CD} 127^{\text {low } /-}$ T lymphocyte predominated in PBMCs of IBCa patients. To investigate the phenotype and subsets of $\mathrm{CD}_{4}^{+} \mathrm{T}$ cells in patients and healthy individuals, PBMCs were isolated from peripheral blood, incubated with CD4-ECD, CD25-PE-cy7, CD127-FITC or PD-1-PE, and analyzed by flow cytometry. (A,B) The percentage of $\mathrm{CD} 4{ }^{+} \mathrm{CD} 25^{+} \mathrm{CD} 127^{\text {low/ }}-\mathrm{T}$ cells was among the highest in PBMCs of IBCa patients $(6.06 \pm 2.17 \%)$ compared with FIBma patients $(2.91 \pm 1.06 \%)$ and health individuals $(2.28 \pm 0.79 \%)$ $\left(P<0.05\right.$ for all). (C,D) The expression of PD- 1 on CD $4^{+} \mathrm{CD} 25^{+} \mathrm{CD} 127^{\text {low }}-$ Tregs in PBMCs of health individuals, FIBma and IBCa patients analyzed by flow cytometry. These was significant difference between the PBMCs of FIBma patients and health individuals $(P<0.05)$. (E) The percentages of CD4 ${ }^{+} \mathrm{T}$ cells in PBMCs of health individuals, FIBma and IBCa patients were $19.90 \pm 9.02 \%, 22.98 \pm 7.51 \%$, and $20.74 \pm 8.84 \%$, respectively. And there no difference was found between health individuals and FIBma patients or health individuals and IBCa patients $(P>0.05)$. (F) The ratio of CD ${ }^{+} \mathrm{CD} 25^{+} \mathrm{CD} 127^{\text {low }}-$ Tregs and CD4 ${ }^{+} \mathrm{T}$ cells was highest in PBMCs of IBCa patients compared with health individuals and FIBma $(P<0.001)$. $(\mathbf{G}, \mathbf{H})$ The expression of PD-1 compartmentalized into two distinct (PD- $1^{\text {lo }}$ and PD- $1^{\text {hi }}$ ) populations. The high level $\mathrm{PD}-1^{\text {hi }}$ expression was found on $\mathrm{CD} 4^{+} \mathrm{CD} 25^{+} \mathrm{CD} 127^{+} \mathrm{T}$ cells $(20.00 \pm 22.15 \%)$ and $\mathrm{CD} 4^{+} \mathrm{CD} 25^{-} \mathrm{T}$ cells $(13.92 \pm 10.15 \%)$, compared with $\mathrm{CD} 4^{+} \mathrm{CD} 25^{+} \mathrm{CD} 127^{\text {low } /-}$ Tregs $(9.57 \pm 7.27 \%)$. And there was significantly difference between $\mathrm{CD} 4{ }^{+} \mathrm{CD} 25^{+} \mathrm{CD} 127^{\text {low/- }}$ Tregs and $\mathrm{CD} 4{ }^{+} \mathrm{CD} 25^{+} \mathrm{CD} 127^{+}$effector T cells $(P<0.05)$. On the other hand, there was high level PD- ${ }^{\text {lo }}$ expression was found on $\mathrm{CD} 4{ }^{+} \mathrm{CD} 25^{+} \mathrm{CD} 127^{\text {low } /-}$ Tregs $(37.17 \pm 19.27 \%)$, compared with $\mathrm{CD} 4{ }^{+} \mathrm{CD} 25^{+} \mathrm{CD} 127^{+}$effector T cells $(31.03 \pm 20.84 \%)$ or $\mathrm{CD} 4^{+} \mathrm{CD} 25^{-} \mathrm{T}$ cells $(23.87 \pm 19.68 \%)(P>0.05$ and $P<0.05$, respectively).

The relationship between $C D 4^{+} T$ cell subsets and $C D 19^{+} B$ cell subsets in IBCa. In our previous studies, we have shown that B cells from IBCa could induce Tregs in vitro ${ }^{12}$. In the present study, we further examined the correlation between $\mathrm{CD}^{+} \mathrm{T}$ cell subsets and $\mathrm{CD} 19^{+} \mathrm{B}$ cell subsets in PBMCs of IBCa patients. The results showed a positive correlation between the percentages of CD4 ${ }^{+} \mathrm{T}$ cells and CD19 ${ }^{+} \mathrm{B}$ cells $(r=0.397$, $P<0.001), \mathrm{CD}^{+}{ }^{\mathrm{CD}} 25^{+} \mathrm{CD} 127^{\text {low } /-}$ Tregs and $\mathrm{CD} 19^{+} \mathrm{CD} 24^{+} \mathrm{CD} 38^{+}$Bregs $(r=0.316, P=0.001), \mathrm{PD}-\mathrm{L} 1^{+}$ Bregs and Bregs $(r=0.267, P=0.007), \mathrm{PD}-\mathrm{L} 1^{+}$Bregs and CD $4^{+} \mathrm{CD} 25^{+} \mathrm{CD} 127^{\text {low } /-}$ Tregs $(r=0.299, P=0.003)$ (Fig. 4A-D). In contrast, PD-L1 ${ }^{+}$Bregs and PD- ${ }^{\text {hi }} \mathrm{CD} 4^{+} \mathrm{CD} 25^{+} \mathrm{CD} 127^{+}$effector $\mathrm{T}$ cells were inversely correlated with each other $(r=-0.220, P=0.031$; Fig. $4 \mathrm{E})$.

\section{Discussion}

Although the overall survival rate has been improved considerably over the past few decades with the advancement of treatment modalities, breast cancer is still the leading causes of cancer mortality in women ${ }^{18}$. The immunosuppression and immune escape are regarded as predicting factors for poor prognosis of solid cancers. 


\begin{tabular}{|c|c|c|c|c|}
\hline \multirow[b]{2}{*}{ Variables } & \multirow{2}{*}{$\begin{array}{c}\text { All } \\
\text { cases }\end{array}$} & \multicolumn{3}{|c|}{$\mathrm{T}$ cells } \\
\hline & & $\mathrm{CD}^{+}$ & $\mathrm{CD}^{+} \mathrm{CD}^{+} 5^{+} \mathrm{CD} 127^{-}$ & $\mathrm{CD}^{+}{ }^{+} \mathrm{CD} 25^{+} \mathrm{CD} 127^{-} \mathrm{PD}^{-1^{+}}$ \\
\hline IDCa & 98 & & & \\
\hline Grade & 98 & & & \\
\hline G1 & 14 & $24.08 \pm 9.13$ & $5.54 \pm 2.09$ & $53.49 \pm 13.66$ \\
\hline G2 & 63 & $20.20 \pm 8.97$ & $6.03 \pm 2.25$ & $45.99 \pm 20.93$ \\
\hline G3 & 21 & $18.90 \pm 7.57$ & $6.57 \pm 1.99$ & $50.60 \pm 12.91$ \\
\hline$P$ & & 0.213 & 0.381 & 0.314 \\
\hline \multicolumn{5}{|c|}{ LN metastasis } \\
\hline No & 48 & $21.68 \pm 16.69$ & $5.90 \pm 2.12$ & $47.27 \pm 17.93$ \\
\hline Yes & 50 & $19.84 \pm 8.75$ & $6.20 \pm 2.23$ & $48.90 \pm 19.37$ \\
\hline$P$ & & 0.303 & 0.496 & 0.671 \\
\hline \multicolumn{5}{|l|}{ TNM } \\
\hline $\mathrm{I}$ & 24 & $23.29 \pm 8.60$ & $5.86 \pm 2.45$ & $43.44 \pm 16.71$ \\
\hline II & 41 & $19.61 \pm 9.10$ & $5.84 \pm 1.70$ & $51.00 \pm 20.57$ \\
\hline III & 24 & $20.81 \pm 7.58$ & $6.45 \pm 2.51$ & $47.29 \pm 15.61$ \\
\hline IV & 9 & $18.91 \pm 11.22$ & $6.46 \pm 2.55$ & $50.15 \pm 21.97$ \\
\hline$P$ & & 0.388 & 0.650 & 0.462 \\
\hline \multicolumn{5}{|l|}{ ER } \\
\hline Negative & 32 & $21.95 \pm 9.38$ & $6.00 \pm 1.77$ & $48.91 \pm 17.99$ \\
\hline Positive & 66 & $20.15 \pm 8.58$ & $6.08 \pm 2.35$ & $47.72 \pm 19.01$ \\
\hline$P$ & & 0.348 & 0.856 & 0.771 \\
\hline \multicolumn{5}{|l|}{ PR } \\
\hline Negative & 56 & $21.63 \pm 9.08$ & $6.01 \pm 1.85$ & $47.06 \pm 18.80$ \\
\hline Positive & 42 & $19.55 \pm 8.48$ & $6.12 \pm 2.56$ & $49.50 \pm 18.47$ \\
\hline$P$ & & 0.252 & 0.793 & 0.529 \\
\hline \multicolumn{5}{|l|}{ HER2 } \\
\hline Negative & 62 & $21.12 \pm 8.87$ & $6.10 \pm 2.41$ & $49.35 \pm 16.97$ \\
\hline Positive & 36 & $20.09 \pm 8.87$ & $5.98 \pm 1.70$ & $45.93 \pm 21.26$ \\
\hline$P$ & & 0.580 & 0.796 & 0.389 \\
\hline \multicolumn{5}{|l|}{ Age } \\
\hline$<49 y$ & 39 & $18.57 \pm 8.66$ & $6.23 \pm 2.21$ & $47.79 \pm 18.32$ \\
\hline$\geq 49 \mathrm{y}$ & 59 & $22.18 \pm 8.74$ & $5.94 \pm 2.16$ & $48.31 \pm 18.94$ \\
\hline$P$ & & 0.047 & 0.510 & 0.894 \\
\hline \multicolumn{5}{|l|}{ Tumor size } \\
\hline$<3 \mathrm{~cm}$ & 59 & $19.96 \pm 8.83$ & $5.89 \pm 2.02$ & $46.66 \pm 18.56$ \\
\hline$\geq 3 \mathrm{~cm}$ & 39 & $21.93 \pm 8.85$ & $6.31 \pm 2.38$ & $50.21 \pm 18.69$ \\
\hline$P$ & & 0.283 & 0.346 & 0.361 \\
\hline
\end{tabular}

Table 1. Relationship between the proportion of $\mathrm{CD4}^{+} \mathrm{T}$ cells and its subset in PBMCs and the clinicopathological parameters of IBCa patients.

Regulatory T cells (Tregs), defined as $\mathrm{CD} 4{ }^{+} \mathrm{CD} 25^{+} \mathrm{Foxp}^{+}$or $\mathrm{CD} 4{ }^{+} \mathrm{CD} 25^{+} \mathrm{CD} 127^{\text {low/- }}$, mediate peripheral tolerance and prevent autoimmunity in healthy individuals. It has been recognized that Tregs serve as a key mediator that regulates and maintains the balance of immune response by suppressing the expansion of effector $\mathrm{T}$ cells ${ }^{19}$. Therefore, Tregs play a beneficial role in treatment of autoimmunity diseases. In contrast, there is usually an increased number of Tregs in the peripheral blood or tumor sites in patients who have cancer, including head and neck squamous cell carcinoma, breast cancer, lung cancer, colorectal cancer, pancreatic cancer, ovarian cancer and melanoma ${ }^{20-22}$. Numerous reports showed Tregs were associated with inhibition of immune response against cancer, tumor immune escape and metastasis ${ }^{19}$. Higher number of Tregs has been associated with higher risk of relapse and shorter relapse-free survival. A recent investigation suggested that Tregs may be an important pathological factor predicting a response to hormone therapy or chemotherapy in breast cancer patients and can be potential therapeutic target for breast cancer $^{23}$. However, the mechanisms that regulate Tregs activity is only beginning to be elucidated.

We have shown in the present study and our previous report $\mathrm{t}^{12}$ that there was a significantly elevated number of $\mathrm{CD} 4^{+} \mathrm{CD} 25^{+} \mathrm{Foxp}^{+}$or CD $4^{+} \mathrm{CD} 25^{+} \mathrm{CD} 127^{-}$Tregs in the PBMCs of IBCa patients compared with that in patients with breast benign tumor or healthy women. We revealed that it was the ratio of $\mathrm{CD} 4^{+} \mathrm{T}$ cells to $\mathrm{CD} 4^{+}$ $\mathrm{CD} 25^{+} \mathrm{CD} 127^{-}$Treg instead of their number changes that governs their suppressive activity. On the other hand, $\mathrm{CD} 19^{+} \mathrm{B}$ cells from IBCa was recently shown to promote the expansiveness of Tregs in a T and B cell co-culture system, and an elevated number of $\mathrm{CD} 19^{+} \mathrm{CD} 24^{+} \mathrm{CD} 38^{+} \mathrm{B}$ cells, identified as Bregs, were found in $\mathrm{IBCa}^{12}$. The majority of studies on Bregs have focused on their suppression in the ranges of autoimmune, allergic conditions 
A

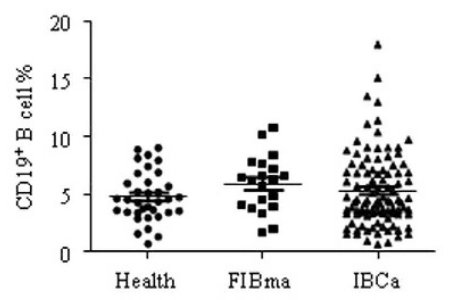

B

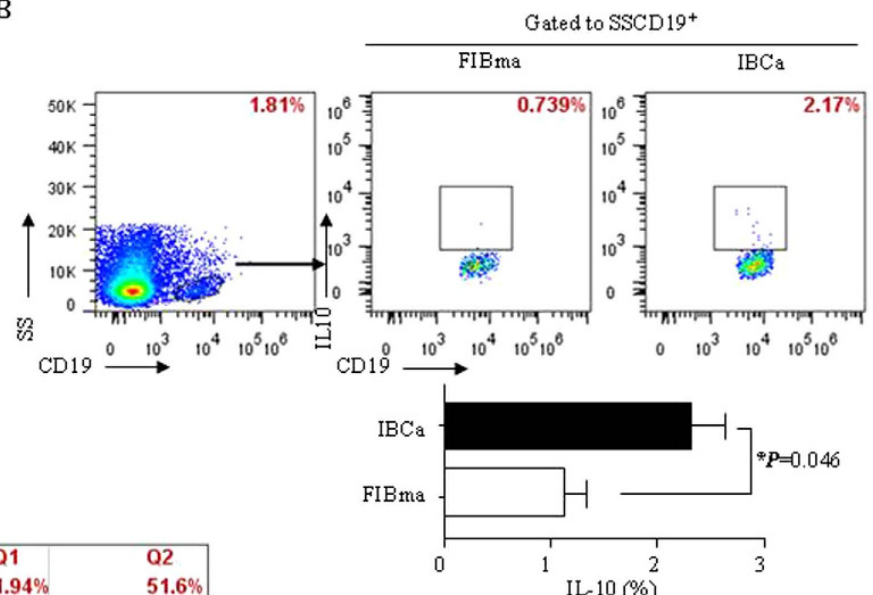

$\mathrm{D}$

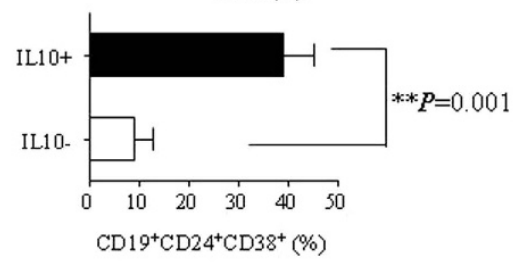

E

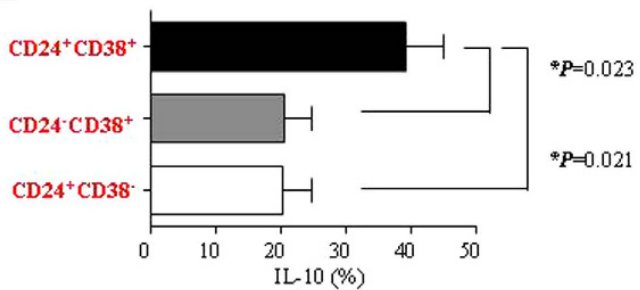

Figure 2. $\mathrm{IL}_{-10}{ }^{+} \mathrm{B}$ cell were enriched with the $\mathrm{CD} 19^{+} \mathrm{CD} 24^{+} \mathrm{CD} 38^{+} \mathrm{B}$ cells population. (A) The percentages of $\mathrm{CD} 19^{+} \mathrm{B}$ cells in PBMCs had no different among FIBma patients, IBCa patients and health individuals $(5.89 \pm 2.44 \%, 5.31 \pm 3.23 \%$, and $4.75 \pm 2.16 \%$, respectively). (B) A higher level of IL-10 (2.31 $\pm 1.01 \%)$ in IBCa patients compared with FIBma patients $(1.12 \pm 0.41 \%)(P=0.046)$. $($ C,D $)$ In our early report, $\mathrm{CD} 19^{+} \mathrm{CD} 24^{+} \mathrm{CD} 38^{+} \mathrm{B}$ cell was identified as regulatory B cells in breast cancer ${ }^{12}$. So, to identify the phenotype of CD $19^{+} \mathrm{L}-10^{+} \mathrm{B}$ cells in PBMCs of IBCa, stained with CD24 and CD38 and analyzed by flow cytometry. A significantly higher percentage of $\mathrm{CD} 24^{+} \mathrm{CD} 38^{+}$in the $\mathrm{CD} 19^{+} \mathrm{IL}-10^{+}$group $(39.18 \pm 5.98 \%)$ compared to that in the $\mathrm{CD} 19^{+} \mathrm{IL}-10^{-}$group $(8.87 \pm 4.08 \%)(P=0.001)$. (E) The higher level of IL-10 secreted by $\mathrm{CD} 19^{+} \mathrm{CD} 24^{+} \mathrm{CD} 38^{+} \mathrm{B}$ lymphocytes $(39.18 \pm 18.91 \%)$ than $\mathrm{CD} 19^{+} \mathrm{CD} 24^{-} \mathrm{CD} 38^{+} \mathrm{B}$ cells $(20.72 \pm 13.01 \%)$ or $\mathrm{CD} 19^{+} \mathrm{CD} 24^{+} \mathrm{CD} 38^{-} \mathrm{B}$ cells $(20.48 \pm 13.46 \%)(P=0.023, P=0.0231)$.

and cancer in both mice and man. The immune regulatory functions of Tregs have been described, yet little is known about the regulatory role B cells toward on Tregs responses against tumor. In the present investigation, significantly high percentage of $\mathrm{CD} 19^{+} \mathrm{CD} 24^{+} \mathrm{CD} 38^{+}$Bregs was seen in the PMBCs of IBCa patients compared with that in benign tumor patients or healthy individuals. A positive correlation between $\mathrm{CD} 19^{+} \mathrm{CD} 24^{+} \mathrm{CD} 38^{+}$ Bregs and $\mathrm{CD} 4^{+} \mathrm{CD} 25^{+} \mathrm{CD} 127^{-}$Tregs was also observed.

We further investigated the function and relationship of PD-L1/PD-1 between Tregs and Bregs. PD-L1 as a ligand of PD-1 is constitutively expressed on B lymophocytes, macrophages and dendritic cells (DCs) ${ }^{15}$. Meanwhile, PD-1 is also inducible on activated T-cell subsets ${ }^{24}$. The PD-1/PD-L1 interaction exerts inhibitory effects that limit effector cells response, prevent the triggering of immune-mediated tissue damage, and regulate the balance between $\mathrm{T}$ cell activation and tolerance ${ }^{25}$. A number of studies have indicated that PD-1/PD-L1 pathway is a crucial modulator of host immune responses in regulation of autoimmunity, tumor immunity, transplantation immunity, and allergy ${ }^{26-28}$. The majority of studies have focused on PD-L1 expressed on DCs or macrophages that suppress effector $\mathrm{CD} 4{ }^{+} \mathrm{T}$ cells ${ }^{26,29}$. In the present study, we analyzed the expression of PD-L1 on $\mathrm{CD} 19^{+} \mathrm{CD} 24^{+} \mathrm{CD} 38^{+}$Bregs in breast tumor patients with and healthy individuals. We confirmed that PD-L1 was higher on $\mathrm{CD} 19^{+} \mathrm{CD} 24^{+} \mathrm{CD} 38^{+}$Bregs in IBCa patients compared with patients with benign tumor or healthy individuals. Though the percentages of CD $19^{+} \mathrm{B}$ cells, CD $19^{+} \mathrm{CD} 24^{+} \mathrm{CD} 38^{+} \mathrm{B}$ cells, and CD $19^{+} \mathrm{CD} 24^{+} \mathrm{CD} 38^{+}$ $\mathrm{PD}-\mathrm{L} 1^{+} \mathrm{B}$ cells were not significantly different in terms of tumor grades, lymph node metastasis, ER, PR, and HER2 status, a tight correlation was seen between upregulated expression of PD-L1 on CD $19^{+} \mathrm{CD} 24^{+} \mathrm{CD} 38^{+}$ Bregs and higher TNM phases of IBCa. More importantly, a tight correlation exists between CD19 ${ }^{+} \mathrm{CD} 24^{+}$ $\mathrm{CD} 38^{+}$Bregs and $\mathrm{PD}-\mathrm{L} 1$ expression in $\mathrm{CD} 19^{+} \mathrm{CD} 24^{+} \mathrm{CD} 38^{+}$Bregs, and $\mathrm{PD}-\mathrm{L} 1$ maybe an important molecule in $\mathrm{CD} 19^{+} \mathrm{CD} 24^{+} \mathrm{CD} 38^{+}$Bregs. We further found that both PD-L1 ${ }^{\text {hi }}$ and PD-L1 ${ }^{\text {lo }}$ was significantly higher on $\mathrm{CD} 19^{+}$ 
A

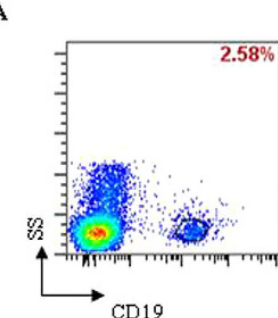

$\mathrm{C}$

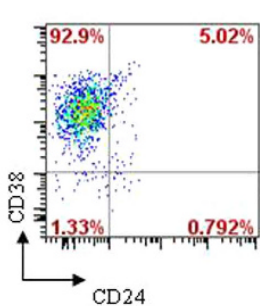

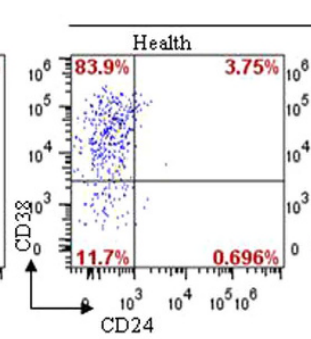

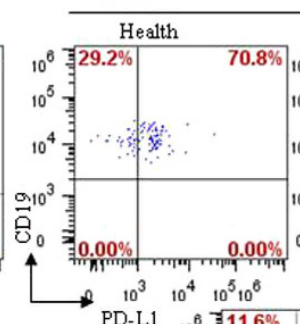

Gated to SSCD $19^{+}$

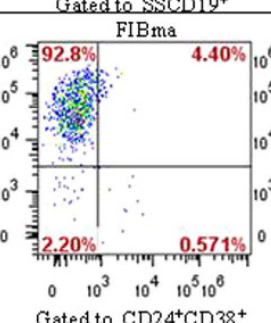

Gated to $C D 24^{+} \mathrm{CD} 38^{+}$

FIBma

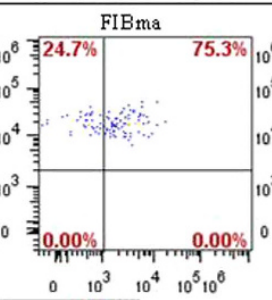

$88.4 \%$ $61.1 \% \quad 21.1 \%$

$\mathrm{E}$

F
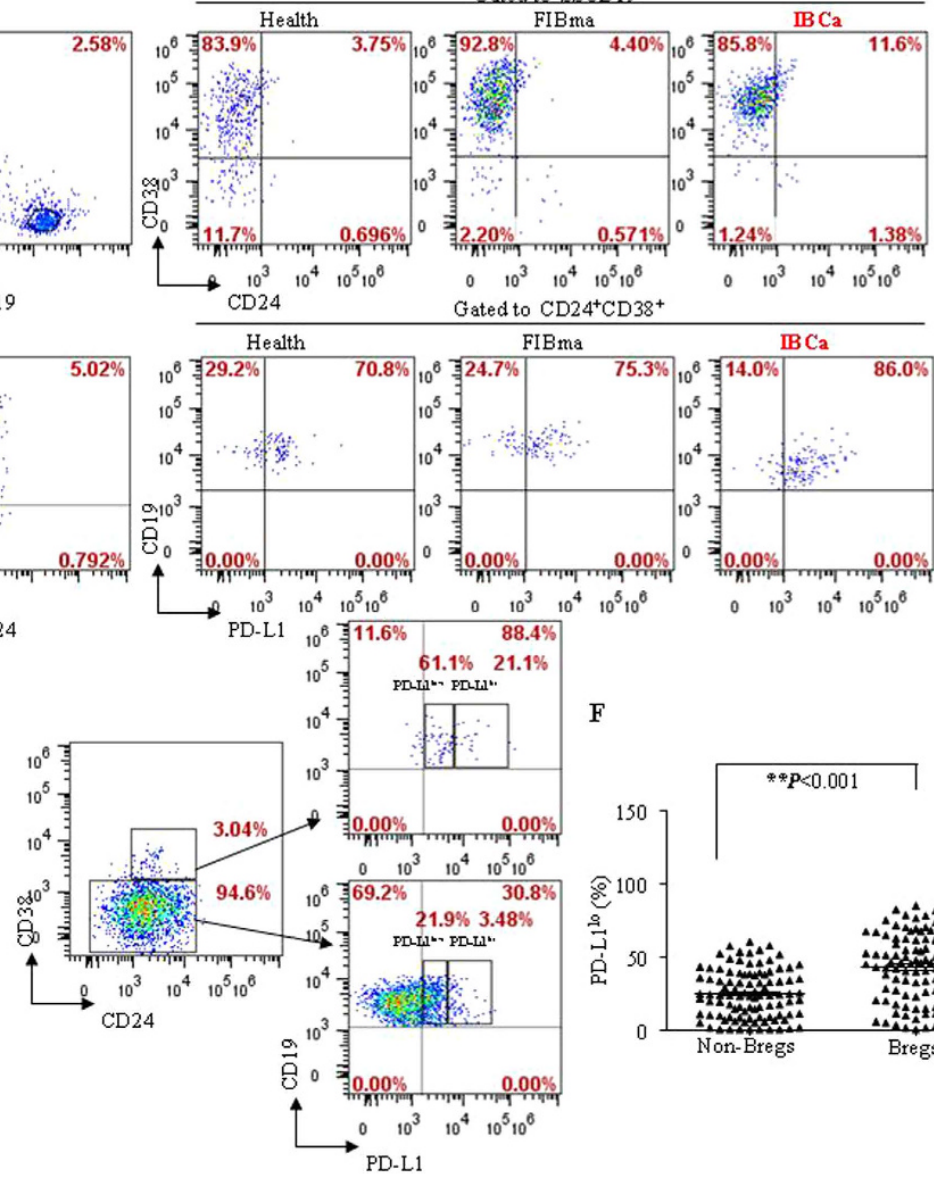

B

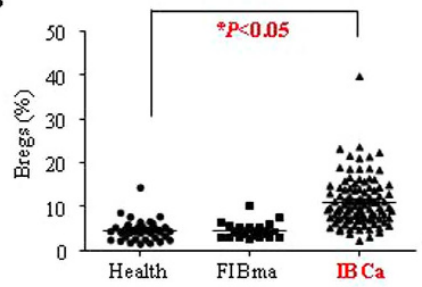

D
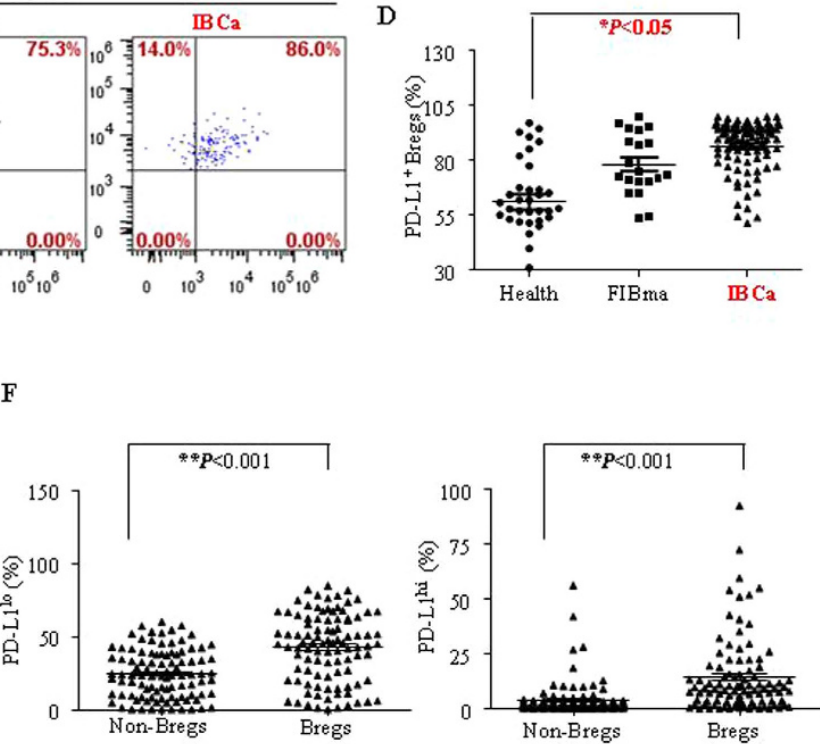

Figure 3. $\mathrm{CD}^{+}{ }^{+} \mathrm{CD}^{+} 4^{+} \mathrm{CD}^{+} 8^{+} \mathrm{B}$ cell and its subsets are expanded in breast cancer patients. $(\mathrm{A}, \mathrm{B})$ The percentage of $\mathrm{CD} 19^{+} \mathrm{CD} 24^{+} \mathrm{CD} 38^{+} \mathrm{B}$ cells in PBMCs of IBCa patients $(10.99 \pm 5.70 \%)$ was significant higher than in that of FIBma patients $(4.48 \pm 1.91 \%)$ and health individuals $(4.49 \pm 2.48 \%)(P<0.05) .(C, D)$ PD-L1 was detected on $\mathrm{CD} 19^{+} \mathrm{CD} 24^{+} \mathrm{CD} 38^{+}$Bregs of breast tumor patients and health individuals. The significant higher $\mathrm{CD} 19^{+} \mathrm{CD} 24^{+} \mathrm{CD} 38^{+} \mathrm{PD}-\mathrm{L1}^{+}$subset $(83.74 \pm 19.32 \%)$ was observed in PBMCs of IBCa patients compared with that in FIBma patients $(78.40 \pm 13.96 \%)$ or health individuals $(61.13 \pm 20.51 \%)(P<0.05)$. $(\mathbf{E}, \mathbf{F})$ The pattern of $\mathrm{PD}-\mathrm{L} 1$ on $\mathrm{CD} 19^{+} \mathrm{CD} 24^{+} \mathrm{CD} 38^{+}$Bregs in PBMCs of IBCa patients was analyzed by cytometry. Wherever PD-L1 ${ }^{\text {lo }}$ or $\mathrm{PD}-\mathrm{L} 1{ }^{\text {hi }}$ expression was significant higher on $\mathrm{CD} 19^{+} \mathrm{CD} 24^{+} \mathrm{CD} 38^{+}$Bregs $(42.36 \pm 23.27 \%$ or $14.02 \pm 16.99 \%)$ than that on Non-Bregs $(24.58 \pm 16.51 \%$ or $3.92 \pm 8.18 \%)$ in $\mathrm{IBCa}(P<0.001$ for all $)$.

$\mathrm{CD} 24^{+} \mathrm{CD} 38^{+}$Bregs compared with that on non-Bregs (CD19+ ${ }^{+} \mathrm{CD} 24^{-} \mathrm{CD} 38^{+} \mathrm{B}$ cells). We therefore speculate that high PD-L1 expression may contribute to the immunosuppressive role of CD $19^{+} \mathrm{CD} 24^{+} \mathrm{CD} 38^{+}$Bregs.

When the expression pattern of PD- 1 on $\mathrm{CD} 4^{+} \mathrm{CD} 25^{+} \mathrm{CD} 127^{-}$Tregs as well as $\mathrm{CD} 4^{+}$non-Tregs was examined, we found that PD- $1^{\text {hi }}$ was mainly expressed on non-Tregs, and the expression level of PD- $1^{\text {lo }}$ was not significantly different between Tregs and non-Tregs. The presence of PD-L1 on CD19 ${ }^{+} \mathrm{CD} 24^{+} \mathrm{CD} 38^{+}$Bregs was found to be positively correlated with $\mathrm{CD} 4^{+} \mathrm{CD} 25^{+} \mathrm{CD} 127^{-}$Tregs, and inversely associated with PD- $1^{\text {hi }}$ non-Tregs. As elegantly described by Adnan et al. ${ }^{30}, \mathrm{PD}-\mathrm{L} 1^{\text {hi }} \mathrm{B}$ cells could suppress inflammation in EAE model through limiting the expansion of $\mathrm{CD}^{+} \mathrm{CXCR}^{+} \mathrm{PD}-1^{+}$follicular helper $\mathrm{T}$ cells $\left(\mathrm{T}_{\mathrm{FH}}\right.$-cell). This, in conjunction with our recent finding that that $\mathrm{CD} 19^{+} \mathrm{B}$ cells from IBCa could promoted Tregs in a T and B cells co-culture system ${ }^{12}$, led us to hypothesize that PD-L1 expressed on Bregs might inhibit the proliferation of PD-1 ${ }^{\text {hi }}$ non-Tregs, and promote the expansion of Tregs to suppress immune response.

As negative function of B cells was demonstrated, B-cell depletion by anti-CD20 antibody was used to augment immunotherapy in multiple solid tumor models ${ }^{31}$. Further investigations confirmed that the absence of $B$ lymphocytes reduced the number and function of Tregs and enhanced the anti-tumor response in a murine tumor model ${ }^{31}$. However, as important immune cells, depletion of B lymphocytes would lead to deficient adaptive immune responses. Furthermore, published studies have showed that the depletion of B lymphocytes by anti-CD20 antibody would enrich CD20 $0^{\text {low/ }-}$ Bregs and promote cancer escape ${ }^{32}$. So, Bregs maybe a useful target cells in tumor immunotherapy base on Breg-mediated immunosuppression. And the precise phenotype of Bregs need identified and further investigated in cancer. Here, we have shown the level of PD-L1 was higher on $\mathrm{CD} 19{ }^{+} \mathrm{CD} 24{ }^{+} \mathrm{CD} 38^{+}$Bregs in $\mathrm{IBCa}$, and the percentage of $\mathrm{PD}-\mathrm{L} 1{ }^{+} \mathrm{CD} 19^{+} \mathrm{CD} 24^{+} \mathrm{CD} 38^{+}$Bregs was positively correlated with Tregs, but negatively correlated with PD- ${ }^{\text {hi }}$ non-Tregs. These observations suggested that 


\begin{tabular}{|c|c|c|c|c|}
\hline \multirow[b]{2}{*}{ Variables } & \multirow[b]{2}{*}{ All cases } & \multicolumn{3}{|c|}{ B cells } \\
\hline & & $\mathrm{CD}^{+} 9^{+}$ & $\mathrm{CD}{ }^{+} \mathrm{CD}^{-} 4^{+} \mathrm{CD} 8^{+}$ & $\mathrm{CD} 9^{+} \mathrm{CD} 24^{+} \mathrm{CD} 8^{+} \mathrm{PD}^{-\mathrm{L}^{+}}$ \\
\hline IDCa & 98 & & & \\
\hline \multicolumn{5}{|l|}{ Grade } \\
\hline G1 & 14 & $5.32 \pm 3.21$ & $9.78 \pm 5.41$ & $82.88 \pm 20.54$ \\
\hline G2 & 63 & $5.17 \pm 3.15$ & $11.83 \pm 6.18$ & $83.09 \pm 21.06$ \\
\hline G3 & 21 & $5.26 \pm 3.18$ & $9.50 \pm 3.69$ & $86.69 \pm 12.63$ \\
\hline$P$ & & 0.985 & 0.178 & 0.751 \\
\hline \multicolumn{5}{|c|}{ LN metastasis } \\
\hline No & 48 & $5.33 \pm 3.60$ & $11.60 \pm 6.84$ & $81.30 \pm 21.63$ \\
\hline Yes & 50 & $5.28 \pm 2.85$ & $10.40 \pm 4.34$ & $86.08 \pm 16.69$ \\
\hline$P$ & & 0.931 & 0.303 & 0.223 \\
\hline \multicolumn{5}{|l|}{ TNM } \\
\hline $\mathrm{I}$ & 24 & $4.74 \pm 2.23$ & $10.61 \pm 5.69$ & $87.30 \pm 9.37$ \\
\hline II & 41 & $5.49 \pm 3.92$ & $11.07 \pm 6.56$ & $76.53 \pm 26.35$ \\
\hline III & 24 & $5.79 \pm 3.00$ & $11.48 \pm 4.67$ & $88.30 \pm 9.73$ \\
\hline IV & 9 & $4.85 \pm 2.72$ & $10.31 \pm 4.66$ & $94.88 \pm 4.72$ \\
\hline$P$ & & 0.700 & 0.939 & 0.011 \\
\hline \multicolumn{5}{|l|}{ ER } \\
\hline Negative & 32 & $6.36 \pm 4.14$ & $11.23 \pm 6.98$ & $82.28 \pm 20.35$ \\
\hline Positive & 66 & $4.79 \pm 2.56$ & $10.87 \pm 5.03$ & $84.44 \pm 18.92$ \\
\hline$P$ & & 0.056 & 0.773 & 0.605 \\
\hline \multicolumn{5}{|l|}{ PR } \\
\hline Negative & 56 & $5.39 \pm 3.61$ & $10.67 \pm 6.17$ & $82.79 \pm 20.31$ \\
\hline Positive & 42 & $5.19 \pm 2.66$ & $11.41 \pm 5.06$ & $84.99 \pm 18.08$ \\
\hline$P$ & & 0.759 & 0.531 & 0.580 \\
\hline \multicolumn{5}{|l|}{ HER2 } \\
\hline Negative & 62 & $5.54 \pm 3.17$ & $10.69 \pm 6.12$ & $83.61 \pm 17.05$ \\
\hline Positive & 36 & $4.90 \pm 3.32$ & $11.50 \pm 4.95$ & $83.96 \pm 22.97$ \\
\hline$P$ & & 0.345 & 0.501 & 0.930 \\
\hline \multicolumn{5}{|l|}{ Age } \\
\hline$<49 y$ & 39 & $5.30 \pm 3.72$ & $12.13 \pm 6.84$ & $82.25 \pm 23.48$ \\
\hline$\geq 49 \mathrm{y}$ & 59 & $5.31 \pm 2.89$ & $10.23 \pm 4.73$ & $84.72 \pm 16.14$ \\
\hline$P$ & & 0.983 & 0.108 & 0.539 \\
\hline \multicolumn{5}{|l|}{ Tumor size } \\
\hline$<3 \mathrm{~cm}$ & 59 & $4.69 \pm 3.03$ & $11.09 \pm 5.17$ & $85.48 \pm 18.81$ \\
\hline$\geq 3 \mathrm{~cm}$ & 39 & $6.24 \pm 3.33$ & $10.83 \pm 6.50$ & $81.21 \pm 20.04$ \\
\hline$P$ & & 0.019 & 0.829 & 0.295 \\
\hline
\end{tabular}

Table 2. Relationship between the proportion of $\mathrm{CD} 19^{+} \mathrm{B}$ cells and its subset in PBMCs and the clinicopathological parameters of IBCa patients.

PD-L1 maybe another important molecule on Bregs, and a critical molecule mediated the promotion of Tregs in advanced breast cancer. $\mathrm{CD} 19^{+} \mathrm{CD} 24^{+} \mathrm{CD} 38^{+} \mathrm{PD}-\mathrm{L} 1{ }^{+}$Bregs may serve as a target in immunotherapy.

\section{Materials and Methods}

Reagents. The following monoclonal antibodies and reagents were used in this study: anti-human CD19ECD (clone: J3-119) (Beckman Coulter Company, Marseille, France) and anti-human CD4-ECD (clone: SFCI12T411) were purchased from Beckman (USA); anti-human CD24-PE-cy7 (clone: eBioSN3), anti-human CD38-APC (clone: HIT2), and anti-human CD25-PE-cy7 (clone: BC96) were from eBiosciencs (San Jose, CA, USA); anti-human CD127-FITC (clone: A019D5) and anti-human PD-1-PE (clone: PD1.3.1.3) were from Miltenyi Biotec (Germany); PDL1-PE (clone: 29E.2A3) was obtained from BioLegend (USA). Fixation/ Permeabilization Kit (with GolgiStop protein transport inhibitor containing monensin) was purchased from BD Company (BD Biosciences, USA). The Isotype control antibodies including FITC Mouse IgG1 (clone: MOPC-21), PE-cy7 Mouse IgG1 (clone: MOPC-21), APC Mouse IgG1 (clone: MOPC-21), PE Mouse IgG2b (clone: MPC11) were purchased from Biolegend (USA). ECD Mouse IgG1 (clone: A07797) was purchased from Beckman (USA). The following antibodies for compensation controls: CD4-FITC (clone: VIT4, Miltenyi Biotec, Germany), CD4-PE (clone: VIT4, Miltenyi Biotec, Germany), CD4-ECD (clone: SFCI12T411, Bechman, USA), CD4-APC (clone: RPA-T4, eBiosciencs, USA), CD4-PE-cy7 (clone: RPA-T4, eBiosciencs, USA). The following antibodies for Fluorescence Minus One (FMO): CD3-FITC (clone: BW264/56, Miltenyi Biotec, Germany), PD-L1-PE 
A

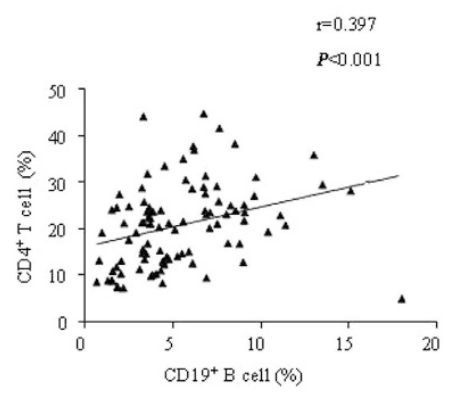

$\mathrm{D}$

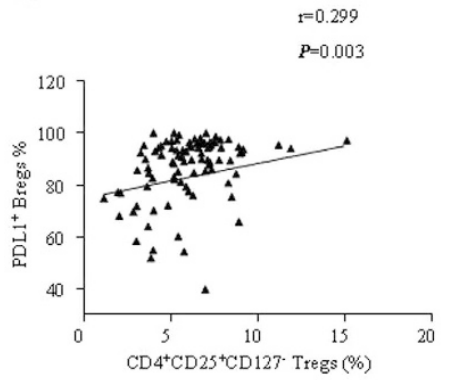

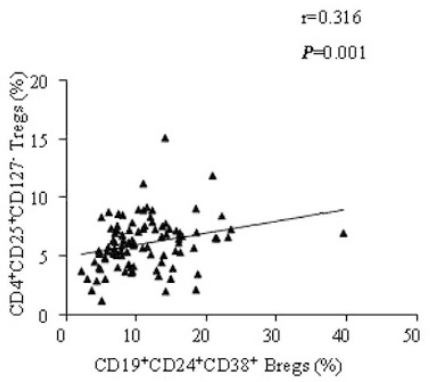

$\mathrm{E}$

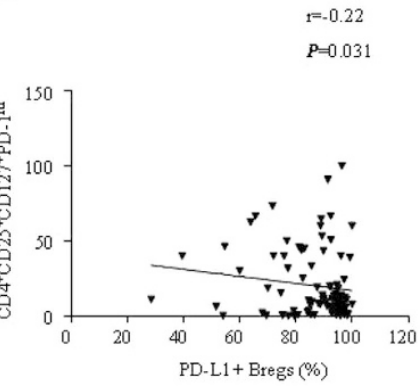

Figure 4. The correlation between $\mathrm{CD}^{+} \mathrm{T}$ cell subsets and $\mathrm{CD}^{+} 9^{+} \mathrm{B}$ cell subsets in IBCa. (A) The positive correlation was found between the percentages of $\mathrm{CD} 4^{+} \mathrm{T}$ cells and $\mathrm{CD} 19^{+} \mathrm{B}$ cells $(r=0.397, P<0.001)$. (B) The positive correlation was found between $\mathrm{CD} 4{ }^{+} \mathrm{CD} 25^{+} \mathrm{CD} 127^{\text {low } /-}$ Tregs and $\mathrm{CD} 19^{+} \mathrm{CD} 24^{+} \mathrm{CD} 38^{+}$Bregs $(r=0.316, P=0.001)$. (C) The positive correlation was found between PD-L1 ${ }^{+}$Bregs and Bregs $(r=0.267$, $P=0.007)$. (D) The positive correlation was found between PD-L1 $1^{+}$Bregs and $\mathrm{CD} 4^{+} \mathrm{CD} 25^{+} \mathrm{CD} 127^{\text {low } /-}$ Tregs $(r=0.299, P=0.003)$. (E) There was significantly negative correlation between PD-L1 ${ }^{+}$Bregs vs PD- $1^{\text {hi }} C D 4^{+}$ $\mathrm{CD} 25^{+} \mathrm{CD} 127^{+}$effector T cells $(r=-0.220, P=0.031)$.

(clone: PD1.3.1.3), CD19-ECD (clone: J3-119), CD4-APC (clone: RPA-T4), CD14-PE 770 (clone: TUK4, Miltenyi Biotec, Germany).

Lipopolysaccharide, PMA and calcium-ionomycin were obtained from Sigma (St Louis, USA).

Patients and peripheral blood cells collection. A total of 153 participants including 98 IBCa, 20 FIBma, and 35 healthy individuals were enrolled in this study. The FIBma patients aged 17-58 years, with a mean of 39.8 years. The healthy individuals aged $25-64$ years, with a mean of 45.7 years. The age range of the IBCa patients was from 31 to 90 years, with a mean of 54.2 years. None of the patients with IBCa had received any kind of chemical or radiation therapy before surgery. The characteristics of the IBCa patients were presented in Table 1.14 out of 98 (14.3\%) IBCa were graded as well-differentiated, $63 / 98$ (64.3\%) were moderately-differentiated and the rest $(21 / 98,21.4 \%)$ were poorly-differentiated. Carcinoma specimens were classified as stage T1 $(24 / 98,24.5 \%), \mathrm{T} 2$ $(41 / 98,41.8 \%), \mathrm{T} 3(24 / 98,24.5 \%)$ and T4 $(9 / 98,9.2 \%)$. In addition, local lymph node metastasis occurred in 50 cases of 98 cases (51.0\%). Peripheral blood cells were collected from IBCa and FIBma patients, and healthy individuals for flow cytometry analysis of cell surface markers. Written informed consent was obtained from each individual participant. The study protocol was performed in accordance with the guidelines outlined in the Declaration of Helsinki and was approved by the Ethics Committee of Soochow University.

Peripheral immune cell isolation. Peripheral blood mononuclear cells (PBMCs) were isolated from blood sample via a ficoll density gradient (Amersham Biosciences, Sweden) centrifugation at $1800 \mathrm{rpm}$ for $20 \mathrm{~min}$ at $4^{\circ} \mathrm{C}$. PBMCs were washed with FACS buffer and centrifuged at $1800 \mathrm{rpm}$ for $5 \mathrm{~min}$ prior to labeling with antibodies for flow cytometry analysis.

Surface staining and flow cytometry. Following isolation, the PBMCs were immediately labelled with the specific fluorochrome-conjugated antibodies including CD4-ECD, CD25-PE-cy7, CD127-FITC and PD-1-PE to identify the surface molecules of Tregs for $30 \mathrm{~min}$ at $4^{\circ} \mathrm{C}$. Labeled cells were re-suspended in $0.5 \mathrm{~mL}$ cell staining buffer, and analyzed using a flow cytometer (CytomicsTM FC500, Beckman Coulter, USA). The data was analyzed using FlowJo software (version 7.6.2, Ashland, OR, USA). Isotype controls were included for each staining. FMO controls were included for assessing background fluorescence. Meanwhile, CD4-FITC, CD4-PE, CD4-ECD and CD4-PE-cy7 were used for compensation. The compensation and FMO controls were performed as shown in Supplementary Figures 2 and 3.

The surface molecules of Breg were analyzed similarly. In brief, PBMCs were incubated with the specific fluorochrome-conjugated antibodies including CD19-ECD, CD38-APC, CD24-PE-cy7 and PD-L1-PE for 
$30 \mathrm{~min}$ at $4{ }^{\circ} \mathrm{C}$. Labeled cells were re-suspended in $0.5 \mathrm{~mL}$ cell staining buffer, and analyzed using flow cytometer with FlowJo software (version 7.6.2, Ashland, OR, USA). Isotype controls were used for each staining, and FMO controls were included to assess background fluorescence. Meanwhile, CD4-PE, CD4-ECD, CD4-APC, and CD4-PE-cy7 were used for compensation.

Intracellular staining of IL-10 and flow cytometry analysis. Intracellular IL-10 staining and analysis by flow cytometry was performed as previously described ${ }^{12}$. Briefly, PBMCs cells were cultured in the RMPI 1640 media containing $10 \%$ fetal calf serum, $200 \mu \mathrm{g} / \mathrm{mL}$ penicillin, $200 \mu \mathrm{g} / \mathrm{mL}$ streptomycin and stimulated with LPS $(1 \mu \mathrm{g} / \mathrm{mL})$ for 72 hour, then stimulated with PMA $(50 \mathrm{ng} / \mathrm{mL})$ and ionomycin $(750 \mathrm{ng} / \mathrm{mL})$ for 6 hour. Four hours prior to the termination, cells were blocked with GolgiStop (BD Biosciences, USA). Bregs were labeled as described above using CD19-ECD, CD24-Pecy7 and CD38-APC. For intracellular staining, cells were fixed with Fixation/Permeabilization solution and incubated with anti-human IL-10-FITC antibody for $30 \mathrm{~min}$ in the dark. Labeled cells were re-suspended in $0.5 \mathrm{~mL}$ cell staining buffer, and analyzed with flow cytometry. Isotype controls and FMO controls were included for all experiments. Meanwhile, CD4-FITC, CD4-PE, CD4-ECD, and CD4-APC, were used for compensation.

Statistical analysis. All of the data were presented as mean \pm standard error of the mean and analyzed using ANOVA-test or Student $t$ test. ANOVA-test and Student-Newman-Keuls (SNK) for post hoc test were used to compare the mean of the percentage of $\mathrm{CD} 4^{+} \mathrm{T}$ cells, $\mathrm{CD} 19^{+} \mathrm{B}$ cells and their subsets in patients, healthy individuals. Correlation was determined by the Pearson correlation. The $P<0.05$ and $P<0.01$ were considered as statistically significant and very significant, respectively. All analyses were done using SPSS 17.0 software (USA).

\section{References}

1. Rosser, E. C. \& Mauri, C. Regulatory B cells in experimental mouse models of arthritis. Methods in molecular biology 1190, 183-194, doi: 10.1007/978-1-4939-1161-5_13 (2014).

2. Blair, P. A. et al. CD19(+)CD24(hi)CD38(hi) B cells exhibit regulatory capacity in healthy individuals but are functionally impaired in systemic Lupus Erythematosus patients. Immunity 32, 129-140, doi: 10.1016/j.immuni.2009.11.009 (2010).

3. Yanaba, K. et al. IL-10-producing regulatory B10 cells inhibit intestinal injury in a mouse model. The American journal of pathology 178, 735-743, doi: 10.1016/j.ajpath.2010.10.022 (2011)

4. Olkhanud, P. B. et al. Tumor-evoked regulatory B cells promote breast cancer metastasis by converting resting CD4(+) T cells to T-regulatory cells. Cancer research 71, 3505-3515, doi: 10.1158/0008-5472.CAN-10-4316 (2011).

5. Ding, T., Yan, F., Cao, S. \& Ren, X. Regulatory B cell: New member of immunosuppressive cell club. Human immunology 76, 615-621, doi: 10.1016/j.humimm.2015.09.006 (2015).

6. Kalampokis, I., Yoshizaki, A. \& Tedder, T. F. IL-10-producing regulatory B cells (B10 cells) in autoimmune disease. Arthritis research \& therapy 15 Suppl 1, S1, doi: 10.1186/ar3907 (2013).

7. Yanaba, K. et al. A regulatory B cell subset with a unique CD1dhiCD5 ${ }^{+}$phenotype controls T cell-dependent inflammatory responses. Immunity 28, 639-650, doi: 10.1016/j.immuni.2008.03.017 (2008).

8. de Masson, A. et al. CD24(hi)CD27(+) and plasmablast-like regulatory B cells in human chronic graft-versus-host disease. Blood 125, 1830-1839, doi: 10.1182/blood-2014-09-599159 (2015).

9. Liu, Y. et al. Role of IL-10-producing regulatory B cells in control of cerebral malaria in Plasmodium berghei infected mice. European journal of immunology 43, 2907-2918, doi: 10.1002/eji.201343512 (2013).

10. Das, A. et al. IL-10-producing regulatory B cells in the pathogenesis of chronic hepatitis B virus infection. Journal of immunology 189, 3925-3935, doi: 10.4049/jimmunol.1103139 (2012).

11. Matsushita, T., Horikawa, M., Iwata, Y. \& Tedder, T. F. Regulatory B cells (B10 cells) and regulatory T cells have independent roles in controlling experimental autoimmune encephalomyelitis initiation and late-phase immunopathogenesis. Journal of immunology 185, 2240-2252, doi: 10.4049/jimmunol.1001307 (2010).

12. Guan, H. et al. PD-L1 mediated the differentiation of tumor-infiltrating CD19 B lymphocytes and T cells in Invasive breast cancer. Oncoimmunology 5, e1075112, doi: 10.1080/2162402X.2015.1075112 (2016).

13. Ray, A., Basu, S., Williams, C. B., Salzman, N. H. \& Dittel, B. N. A novel IL-10-independent regulatory role for B cells in suppressing autoimmunity by maintenance of regulatory T cells via GITR ligand. Journal of immunology 188, 3188-3198, doi: 10.4049/ jimmunol.1103354 (2012).

14. Lin, M., Wang, Z. \& Han, X. B Cells with Regulatory Function in Animal Models of Autoimmune and Non-Autoimmune Diseases. Open J Immunol 5, 9-17, doi: 10.4236/oji.2015.51002 (2015).

15. Amarnath, S. et al. The PDL1-PD1 axis converts human TH1 cells into regulatory T cells. Science translational medicine 3, 111ra120, doi: 10.1126/scitranslmed.3003130 (2011).

16. Yi, T. et al. Host APCs augment in vivo expansion of donor natural regulatory T cells via B7H1/B7.1 in allogeneic recipients. Journal of immunology 186, 2739-2749, doi: 10.4049/jimmunol.1002939 (2011).

17. Yang, Z. Z. et al. PD-1 expression defines two distinct T-cell sub-populations in follicular lymphoma that differentially impact patient survival. Blood cancer journal 5, e281, doi: 10.1038/bcj.2015.1 (2015).

18. Ferlay, J. et al. Cancer incidence and mortality worldwide: sources, methods and major patterns in GLOBOCAN 2012. International journal of cancer. Journal international du cancer 136, E359-E386, doi: 10.1002/ijc.29210 (2015).

19. Elpek, K. G., Lacelle, C., Singh, N. P., Yolcu, E. S. \& Shirwan, H. CD $4^{+}$CD $25^{+}$T Regulatory Cells Dominate Multiple Immune Evasion Mechanisms in Early but Not Late Phases of Tumor Development in a B Cell Lymphoma Model. The Journal of Immunology 178, 6840-6848, doi: 10.4049/jimmunol.178.11.6840 (2007).

20. Martin-Orozco, N. et al. Melanoma cells express ICOS ligand to promote the activation and expansion of T-regulatory cells. Cancer research 70, 9581-9590, doi: 10.1158/0008-5472.CAN-10-1379 (2010).

21. Corthay, A. How do regulatory T cells work? Scandinavian journal of immunology 70, 326-336, doi: 10.1111/j.1365-3083.2009.02308.x (2009).

22. Wakamatsu, E., Mathis, D. \& Benoist, C. Convergent and divergent effects of costimulatory molecules in conventional and regulatory CD4 ${ }^{+} \mathrm{T}$ cells. Proceedings of the National Academy of Sciences of the United States of America 110, 1023-1028, doi: 10.1073/pnas.1220688110 (2013).

23. Su, M., Huang, C. X. \& Dai, A. P. Immune Checkpoint Inhibitors: Therapeutic Tools for Breast Cancer. Asian Pacific journal of cancer prevention: APJCP 17, 905-910 (2016).

24. Liu, M. F., Weng, C. T. \& Weng, M. Y. Variable increased expression of program death-1 and program death-1 ligands on peripheral mononuclear cells is not impaired in patients with systemic lupus erythematosus. Journal of biomedicine \& biotechnology 2009, 406136, doi: 10.1155/2009/406136 (2009). 
25. Hamel, K. M. et al. B7-H1 expression on non-B and non-T cells promotes distinct effects on T- and B-cell responses in autoimmune arthritis. European journal of immunology 40, 3117-3127, doi: 10.1002/eji.201040690 (2010).

26. Zhang, Y. et al. Upregulation of programmed death-1 on T cells and programmed death ligand-1 on monocytes in septic shock patients. Critical Care 15, R70, doi: 10.1186/cc10059 (2011).

27. Butt, A. Q. \& Mills, K. H. Immunosuppressive networks and checkpoints controlling antitumor immunity and their blockade in the development of cancer immunotherapeutics and vaccines. Oncogene 33, 4623-4631, doi: 10.1038/onc.2013.432 (2014).

28. Salem, M. L. \& El-Badawy, A. Programmed death-1/programmed death-L1 signaling pathway and its blockade in hepatitis $\mathrm{C}$ virus immunotherapy. World journal of hepatology 7, 2449-2458, doi: 10.4254/wjh.v7.i23.2449 (2015)

29. Pardoll, D. M. The blockade of immune check points in cancer immunotherapy. Nature reviews. Cancer 12, 252-264, doi: 10.1038/ nrc3239 (2012).

30. Khan, A. R. et al. PD-L1hi B cells are critical regulators of humoral immunity. Nature communications 6, 5997, doi: 10.1038/ ncomms6997 (2015).

31. Kim, S. et al. B-cell depletion using an anti-CD20 antibody augments antitumor immune responses and immunotherapy in nonhematopoetic murine tumor models. Journal of immunotherapy 31, 446-457, doi: 10.1097/CJI.0b013e31816d1d6a (2008).

32. Bodogai, M. et al. Anti-CD20 antibody promotes cancer escape via enrichment of tumor-evoked regulatory B cells expressing low levels of CD20 and CD137L. Cancer research 73, 2127-2138, doi: 10.1158/0008-5472.CAN-12-4184 (2013).

\section{Acknowledgements}

This work was supported in part by the National Natural Science Foundation of China (81372343); the Priority Academic Program Development of Jiangsu Higher Education Institutions (PAPD). We thank Mr. Yu Chen from Clinical Immunology Institute for analysis of flow data and review of the manuscript.

\section{Author Contributions}

F.X., H.G., Z.M.W., Y.W. and X.Z. conceived and designed the study and helped to draft the manuscript. Y.S. and Y.W. performed the statistical analysis. Y.W., J.L., Z.Y.W., Q.W., Y.L. and J.Z. performed the data collection and Flow cytometry analysis. All authors reviewed the manuscript.

\section{Additional Information}

Supplementary information accompanies this paper at http://www.nature.com/srep

Competing financial interests: The authors declare no competing financial interests.

How to cite this article: Guan, H. et al. PD-L1 is a critical mediator of regulatory B cells and T cells in invasive breast cancer. Sci. Rep. 6, 35651; doi: 10.1038/srep35651 (2016).

(c) (i) This work is licensed under a Creative Commons Attribution 4.0 International License. The images

or other third party material in this article are included in the article's Creative Commons license, unless indicated otherwise in the credit line; if the material is not included under the Creative Commons license, users will need to obtain permission from the license holder to reproduce the material. To view a copy of this license, visit http://creativecommons.org/licenses/by/4.0/

(C) The Author(s) 2016 